\title{
The Use of Kolb's Model in Science Teaching Methodology
}

\section{El uso del modelo de Kolb en la metodología de enseñanza de las ciencias}

\section{Snježana Močinić*}

Juraj Dobrila University of Pula, Pula, Croatia ORCID: https://orcid.org/0000-0002-6230-2480

\section{Nevenka Tatkovićci}

Juraj Dobrila University of Pula, Pula, Croatia ORCID: https://orcid.org/0000-0002-9329-1438

\section{Sanja Tatković}

Juraj Dobrila University of Pula, Pula, Croatia ORCID: https://orcid.org/0000-0001-8278-2699

*Correspondence

Email: s.moini7@tanu.pro
Cite as:

Močinić, S., Tatković, N., \& Tatković, S. (2020). The Use of Kolb's Model in Science Teaching Methodology. Propósitos y Representaciones, 8 (SPE2), e684. Doi: http://dx.doi.org/10.20511/pyr2020.v8nSPE2.685 


\section{Summary}

The relevance of this paper refers to the importance of Kolb's model in developing future teachers' professional competences and ability to integrate the theoretical and practical segment of their education. The aim of this paper is to examine what theoretical knowledge and practical experience is present in the Science Teaching Methodology regarding the initial teacher training in Croatia, in accordance with the Kolb's model. The research was based on quantitative (descriptive analysis and factor analysis) and qualitative research methodology, which included the analysis of relevant literature and a survey conducted among the students of teacher education studies at the universities of Pula, Rijeka, Zadar and Split (Croatia). The results have shown that, in the given context, the Science Teaching Methodology is dominated by the acquisition of theoretical knowledge, lacking concrete experience activities and reflections on the real-life experience. Furthermore, innovations are only rarely introduced into teaching, which means that Kolb's experiential learning model is not implemented in practice. The paper materials may be useful in the initial teacher training for acquiring the theoretical and practical knowledge about the use of Kolb's model in the Science Teaching Methodology, and for integrating this model into the initial teacher training curriculum.

Keywords: Abstract Conceptualization; Active Experimentation; Artificially Created Subject; Concrete Experience; Teacher Training; Reflective Observation.

\section{Resumen}

La relevancia de este documento se refiere a la importancia del modelo de Kolb en el desarrollo de las competencias profesionales y la capacidad de los futuros docentes para integrar el segmento teórico y práctico de su educación. El objetivo de este trabajo es examinar qué conocimiento teórico y experiencia práctica está presente en la Metodología de la Enseñanza de las Ciencias con respecto a la formación inicial de docentes en Croacia, de acuerdo con el modelo de Kolb. La investigación se basó en metodología de investigación cuantitativa (análisis descriptivo y análisis factorial) y cualitativa, que incluyó el análisis de literatura relevante y una encuesta realizada entre los estudiantes de estudios de formación docente en las universidades de Pula, Rijeka, Zadar y Split (Croacia) . Los resultados han demostrado que, en el contexto dado, la Metodología de la Enseñanza de las Ciencias está dominada por la adquisición de conocimientos teóricos, que carece de actividades de experiencia concretas y reflexiones sobre la experiencia de la vida real. Además, las innovaciones rara vez se introducen en la enseñanza, lo que significa que el modelo de aprendizaje experimental de Kolb no se implementa en la práctica. Los materiales en papel pueden ser útiles en la formación inicial del profesorado para adquirir el conocimiento teórico y práctico sobre el uso del modelo de Kolb en la Metodología de la Enseñanza de las Ciencias, y para integrar este modelo en el plan de estudios inicial de formación del profesorado.

Palabras clave: Conceptualización abstracta; Experimentación activa; Materia creada artificialmente; Experiencia concreta; Formación del profesorado; Observación reflexiva.

\section{Introduction}

On a daily basis we are facing rather significant and quick changes in all segments of life, from social and cultural to socio-economic and political. One of the segments which has undergone significant changes is the education area, i.e. higher education, and those changes are reflected in 
the demand for high-quality, competitive study programs for younger generations and a high level of professional competences for their future employment. One of the key issues of education policy of any country which strives to improve the quality of its education system is teacher education and professional development, because the level of students' learning outcomes largely depends on the quality of the teaching staff. Therefore, the importance of teacher competences, especially those acquired during their initial training, has become the topic of study at all levels of formal education, both in Croatia and worldwide. According to the recommended literature, it is advisable for initial teacher training to be based on a successful combination of theoretical and practical teaching with an appropriate amount of academic and pedagogical/psychological content knowledge, methodology exercises and student practice. To ensure high-quality professional work of prospective teachers it is important to raise awareness among students that theoretical knowledge does not offer prescriptions for dealing with different individual cases they might encounter in their practice.

However, theoretical knowledge is necessary for reflection on experience, and the results of the reflection should be systematized and generalized, allowing the gained knowledge to be applied in different situations. This opens a new perspective in which theory accompanies practice, describing its processes and results and justifying its existence through concrete actions. It is our belief that the use of Kolb's experiential learning model (Kolb, 1984; Kolb, 2015) during initial teacher training can prepare future teachers for the analysis of their practical work by means of theoretical knowledge and reflection.

The main objective of this research was to examine the extent to which theoretical knowledge and practical experience are present and integrated into the Science Teaching Methodology classes during teachers' initial training, and hence also into the process of development of teachers' competences according to Kolb's (1984) experiential learning model. The following research tasks were derived from the general research objective:

-to determine whether theoretical and practical components of Kolb's experiential learning model can be found in the Science Teaching Methodology classes at teacher education studies in Croatia;

-to determine whether theoretical and practical components of Kolb's experiential learning model are integrated into the Science Teaching Methodology classed at teacher education studies in Croatia.

Based on the defined research objective and research tasks, the following hypotheses have been formulated:

(H1) Theoretical (reflective observation and abstract conceptualization) and practical (concrete experience and active experimentation) components of Kolb's experiential learning model are not equally present in Science Teaching Methodology classes at teacher education studies in Croatia.

(H2) Theoretical (reflective observation and abstract conceptualization) and practical (concrete experience and active experimentation) components of Kolb's experiential learning model are not integrated into the Science Teaching Methodology classes at teacher education studies in Croatia. 


\section{Theoretical overview}

\section{Characteristics of the course on Science Teaching Methodology and Science and Social Studies as a subject}

Science Teaching Methodology is an interdisciplinary scientific discipline which studies principles of education from the perspective of Science and Social Studies as a subject taught during primary education (De Zan, 2005). The subject itself is interdisciplinary, integrating "scientific knowledge from the area of natural sciences, social sciences and humanities with technical and computer sciences" (MoSES, 2016). Science and Social Studies are an artificially created subject which is taught from the first to the fourth grade of primary school and which is closely connected with other subjects, cross-curricular topics and curriculum areas by means of the basic concepts it studies. In the delivery of the said subject, "experiential, research-oriented and problem-solving teaching" is recommended, "in which the student is at the center of the learning process, as it ensures his or her active role in learning and teaching" (MoSES, 2016).

Numerous authors believe that extra-classroom, i.e. outdoor teaching (school yard, playground, green areas, various places in which human activities are performed) is also useful, where research-based teaching techniques can be implemented (Szczepanski, 2001; Anđić, 2007; Borić, 2009; Borić et al., 2010; Letina, 2016). This type of teaching is based on observation and perception of various natural and social phenomena, hypothesizing, experimentation, autonomous data collection, analysis and interpretation of results, which help develop critical thinking skills and observe patterns and consequences, as well as other relationships between phenomena. In order to ensure that a future teacher is able to apply the research-based approach to learning and teaching in his/her professional work, it is advisable to practice the said approach during one's own education and training. Seen that Kolb's (Kolb, 1984; Kolb, 2015) experiential learning model has numerous characteristics of research-based teaching, we believe that its use within Science Teaching Methodology might contribute to teachers' training for the implementation of research-based approach in Science and social studies classes.

\section{Kolb's interpretation of the experiential learning model}

Kolb (1984) claims that experiential learning theory would be incomplete without an overview of theories of cognition, nature and organization of knowledge and processes by means of which individuals contribute to and participate in knowledge creation. In his overview of the history of epistemology Kolb draws on empirical, rationalist and interactionist perspectives of knowledge acquisition, believing that they are fundamental for epistemological debate in the western philosophy from the period of classical Greek philosophers up to the 20th century. Apart from the world-view characteristic for medieval scholasticism, the 17th century saw the emergence of the rational, and later empirical theory of cognition. Rationalists such as Descartes, Spinoza and Leibniz (Kolb, 1984) believed that the truth is discovered through logical thinking and reason, in which ideas exist a priori, and that the only thing that stems from senses is the reflection of ideal forms which make sense of the real world.

The 18th century gave rise to the antithesis to rationalism - empiricism. According to empirical philosophers, Locke, Hobbes and others, knowledge derives from sensory experience of the world around us. The mind is a tabula rasa; it receives and records a multitude of sensory experiences, but does not contribute to identifying the essence of things. The conception that truth can be gained through a careful observation of the world has inspired numerous scientific research studies in the 18th century. In the 19th century, rational and empirical views were synthesized in Kant's critical idealism. According to Kant, the mind possesses a priori concepts which allow it to interpret experience, especially those which allow the understanding of time, space and order. The laws of geometry and logic were considered to be extra-experiential, but necessary for the interpretation of experience. In critical idealism, the truth is the product of interaction of the mind and material facts of sensory experience. 
Kolb's (1984) theory of experiential learning conquered the limitations of both rationalism and empiricism. Namely, epistemology of experiential learning is based on the dualknowledge theory: concrete empirical experience, which grasps reality through the process of direct cognition, and rationalist abstract conceptualization, which perceives reality through the abstract thinking mediation process. Unlike Kant, Kolb (1984) argues that ideas are not fixed and unchangeable, but rather shaped and re-shaped on the basis of new experience. Furthermore, knowledge is created through a revised interpretation of the meaning of an experience, which guides subsequent action. Hence, the experiential learning theory defines learning as a "process in which knowledge is created through transformation of experience. Knowledge results from the combination of grasping and transforming experience" (Kolb, 1984). Aware of the complexity of the process, Kolb (1984) tried to illustrate it by using specific descriptive and interpretative categories. For this purpose he used two complementary dimensions: the act of grasping experience and the act of transforming experience. The act of grasping has two aspects: apprehension and comprehension. The former is based on concrete sensory experience, while the latter is based on mental concepts and theoretical interpretation of experience. Within the experience transformation process he distinguishes other two forms - the act of extension (active manipulation of the outside world) and the act of intention (reflective thinking) (Figure 1).

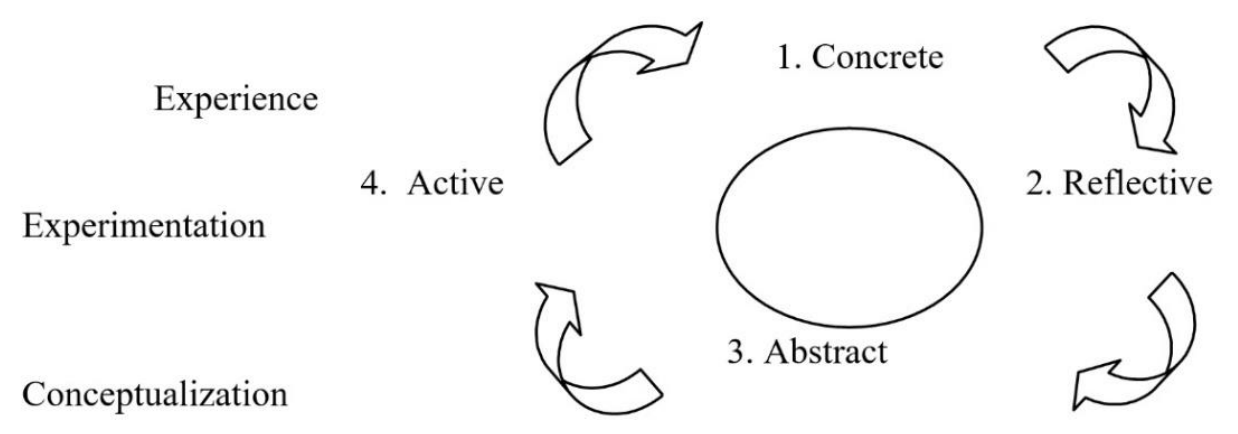

Figure 1. Kolb's cyclic model of experiential learning (Kolb, 1984)

To simplify, in the development of his model, Kolb (Kolb, 1984; Kolb, 2015) begins by defining two crucial dimensions that the learning process depends on, which are: access to information and transformation of information. Access to information can occur through concrete experience or abstract conceptualization, while transformation of experience requires two manners of processing information: reflective observation and active experimentation (Vizek Vidović \& Vlahović-Štetić, 2007). These four elements also represent Kolb's (1984) experiential learning model which consists of four stages: concrete experience, reflective observation, abstract conceptualization and active experimentation. If none of the stages is omitted, an in-depth approach to learning and understanding of the link between theoretical concepts and specific practical issues can be achieved.

Kolb sees the learning process as the context in which individuals move between concrete experience (CE), abstract conceptualization (AC), reflective observation (RO) and active experimentation (AE). Hence, the effectiveness of learning depends on the ability to balance between these four stages of learning, which Kolb views as dialectically linked activities, effective in promoting learning. In the experiential learning process, two aspects can be regarded as especially noteworthy: the use of the concrete, "here and now" experience to test ideas and the use of feedback to change practices and theories (Kolb, 1984) (Table 1). 
Table 1.

Stages and forms of experiential learning (Kolb \& Kolb, 2005)

\begin{tabular}{lll} 
Grasping reality & $\begin{array}{l}\text { Abstract conceptualization } \\
\text { Concrete experience }\end{array}$ & $\begin{array}{l}\text { Thinking, formulating ideas } \\
\text { Experience through the senses }\end{array}$ \\
Transforming reality & $\begin{array}{l}\text { Active experimentation } \\
\text { Reflective observation }\end{array}$ & $\begin{array}{l}\text { Acting, testing ideas in practice } \\
\text { Reflecting on the experience and } \\
\text { activity }\end{array}$ \\
\hline
\end{tabular}

D.A. Kolb and R. Fry (Kolb \& Fry, 1975) argue that the learning cycle can begin at any of the four stages, and that the learning process should be approached as a continuous spiral development. Also, all four stages of the process need to occur for learning to be accomplished. Arising from the belief that learning is a social process based on cumulative experience and reflection on that experience, Kolb (Passarelli \& Kolb, 2011; Kolb, 2015) has a rather broad understanding of the theory of experiential learning, i.e. he believes that it is applicable not only in formal education, but in all life situations and all human activities. The holistic and dynamic nature of the learning process means that it occurs at all levels of human society, from individuals to groups, from education institutions to the society as a whole.

\section{Materials and methods}

This research was based on quantitative and qualitative research methodology which included a survey conducted among students of Teacher Education Studies at the Universities of Pula, Rijeka, Zadar and Split. Kolb's (Kolb, 1984; Kolb, 2015) experiential learning model was chosen as the relevant theoretical framework, although it is not easily applicable to educational conditions and traditions in Croatia, and there is no adequate operationalization or measures appropriate to our socio-cultural context for the constructs that we wanted to explore and correlate with a desirable education practice. Hence, before conducting a concrete empirical research we developed a research measurement instrument (questionnaire) which helped us to achieve the set objectives. The starting point for this research was the experiential learning model (Kolb, 1984; Kolb, 2015) which consists of four stages: concrete experience, reflective observation, abstract conceptualization and active experimentation and which, according to its author, provides an indepth approach to learning and understanding of the connection between theoretical concepts and specific practical problems, and allows the development of competences such as the ability to integrate declarative, procedural and meta-cognitive knowledge. D.A. Kolb and R. Fry (Kolb \& Fry, 1975) believe that the learning cycle can begin at any one of the four stages, and that the learning process should be approached as a continuous spiral development.

Also, for learning to be accomplished, all four stages of the process need to occur. In this research, Kolb's psychological model was attributed the following pedagogical/didactic meanings:

- concrete experience refers to observation of teaching or one's own delivery of a teaching unit;

- reflective observation includes the assessment of one's own or somebody else's practical activity by analysing the pedagogical situation from various perspectives;

- abstract conceptualization refers to the logical analysis of experience, identification of behaviour patterns, the establishment of links with theoretical knowledge, planning and predicting on the basis of what has been observed;

- while active experimentation refers to the testing of the drawn conclusions in a new pedagogical situation (Vizek Vidović, 2005). 
Items have been created and grouped into scales according to the postulates of Kolb's theoretical model of experiential learning. The scales contained in this questionnaire are the following:

- the knowledge acquisition scale, which refers to the acquisition of theoretical knowledge as the basis for further learning and which is not a part of Kolb's experiential learning cycle;

- the concrete experience scale, which examines the respondents' personal experience with observation, planning and delivery of teaching;

- the reflective observation scale, which refers to the reflection during and after one's own class delivery or after observing someone else's class delivery, i.e. video recordings of good practice examples;

- the abstract conceptualization scale, which includes items used to evaluate the logical analysis and explanation of various pedagogical situations, establishment of links with theoretical knowledge, and forecasting of innovations on the basis of acquired knowledge;

- the active experimentation scale, which consists of items used to evaluate the application of acquired knowledge in a new pedagogical situation.

Using a five-point Likert scale (where 1 stands for "not at all", and 5 stands for "absolutely"), respondents were asked to evaluate the extent to which each of the stages of Kolb's experiential learning model is present in the aforementioned scales. The developed instrument was checked for satisfactory metric characteristics. Sensitivity was tested by means of measures of dispersion, construct validity was tested by means of factor analysis, while reliability was tested by means of Cronbach's alpha internal consistency method. Internal consistency coefficients (Cronbach's alpha) obtained for all previously mentioned scales were extremely high, ranging from 0.863 to 0.932 . Data obtained by means of the survey has been processed by means of descriptive statistics and factor analysis. This research encompassed a total of 109 4th- and 5thyear students of Teacher Education Studies of the Universities of Pula, Rijeka, Zadar and Split (Table 2).

Table 2.

Number of students who completed the Science Teaching Methodology questionnaire with regard to the university and the year of study

\begin{tabular}{|c|c|c|c|c|c|}
\hline Measuring instrument & Place of study & (Univer & & & \\
\hline \multirow{4}{*}{$\begin{array}{l}\text { Science Teaching } \\
\text { Methodology } \\
\text { questionnaire }\end{array}$} & Pula & Rijeka & Zadar & Split & Total \\
\hline & 20 & 25 & 30 & 36 & 109 \\
\hline & Year of study & & & & \\
\hline & 2nd year & 3rd year & $\begin{array}{l}\text { 4th year } \\
35\end{array}$ & $\begin{array}{l}\text { 5th year } \\
76\end{array}$ & $\begin{array}{l}\text { Total } \\
109\end{array}$ \\
\hline
\end{tabular}

In the survey on Science Teaching Methodology, the largest number of students who completed the questionnaire were 5th-year students because the said course in teaching methodology is taught at the 4th and the 5th year of teacher education studies at the Universities of Pula, Rijeka and Split, while at the Faculty of Teacher Education of the University of Zadar it is taught at the 3rd and 4th year; however, 3rd-year students were not encompassed by the survey. For the purpose of surveying the students, the questionnaires were sent via mail to the aforementioned Faculties of Teacher Education.

\section{Results and discussion}




\section{Results of the factor analysis in the scales}

The conducted factor analysis has shown that the acquisition of knowledge from Science Teaching Methodology is a multi-dimensional construct. Three factors whose characteristic root exceeds 1 (characteristic root of the selected three factors: 10.930, 1.718, and 1.578) have been singled out, accounting for $61.853 \%$ of the scale score variance. With regard to the size of the coefficient in the matrix shown in Table 3, the first factor was named Familiarity with didactic and methodological contents of Science Teaching Methodology (items 1 to 10); the second factor was named Familiarity with the key features of the subject "Science and social studies" (items 12 to 16); while the third factor was named Familiarity with the essential curriculum contents of Science Teaching Methodology (items 17 to 23 and item 11). On the basis of the aforementioned factor analysis, three eponymous sub-scales have been constructed.

Table 3.

Results of the factor analysis of the knowledge acquisition scale for the Science Teaching Methodology and the descriptive statistics of the items of the scale

\begin{tabular}{|c|c|c|c|c|c|}
\hline \multirow{2}{*}{$\begin{array}{l}\text { Acquisition of theoretical knowledge from the Science } \\
\text { Teaching Methodology }\end{array}$} & \multicolumn{3}{|c|}{ Factor* } & \multirow[t]{2}{*}{$\begin{array}{l}\text { Arithmetic } \\
\text { mean }\end{array}$} & \multirow[t]{2}{*}{$\begin{array}{l}\text { Standard } \\
\text { deviation }\end{array}$} \\
\hline & 1 & 2 & 3 & & \\
\hline $\begin{array}{l}\text { 1. Define the sources of knowledge in the course on } \\
\text { Science and social studies }\end{array}$ & 0.830 & & & 3.990 & 0.893 \\
\hline $\begin{array}{l}\text { 2. Describe the use of teaching instruments and teaching } \\
\text { aids, as well as of information and communication } \\
\text { technology in the course on Science and social studies }\end{array}$ & 0.827 & & & 4.000 & 0.957 \\
\hline $\begin{array}{l}\text { 3. Describe specific traits of social forms of teaching in } \\
\text { the course on Science and social studies }\end{array}$ & 0.775 & & & 4.254 & 0.828 \\
\hline 4. Define the process of lesson preparation & 0.697 & & & 4.036 & 0.917 \\
\hline $\begin{array}{l}\text { 5. Identify possibilities of inter-subject and cross-subject } \\
\text { correlation of teaching contents }\end{array}$ & 0.626 & & & 4.045 & 0.871 \\
\hline 6. Define teaching strategies, methods and procedures & 0.606 & & & 4.045 & 0.794 \\
\hline $\begin{array}{l}\text { 7. Describe personal and professional characteristics and } \\
\text { competences of a successful teacher }\end{array}$ & 0.530 & & & 3.727 & 1.039 \\
\hline $\begin{array}{l}\text { 8. Describe locations in which Science and social studies } \\
\text { course is delivered and their advantages }\end{array}$ & 0.522 & & & 3.972 & 0.817 \\
\hline $\begin{array}{l}\text { 9. Describe the procedures for planning and } \\
\text { programming of the teaching process }\end{array}$ & 0.507 & & & 4.036 & 0.866 \\
\hline $\begin{array}{l}\text { 10. Define the process of concept formation in Science } \\
\text { and social studies class }\end{array}$ & 0.462 & & $\overline{0}-397$ & 3.736 & 0.895 \\
\hline $\begin{array}{l}\text { 11. Identify curriculum contents related to } \\
\text { environmental education and the importance of raising } \\
\text { environmental awareness }\end{array}$ & 0.438 & & $-\overline{0} \cdot 318$ & 3.819 & 0.833 \\
\hline $\begin{array}{l}\text { 12. Define the theoretical postulates and structure of the } \\
\text { teaching methodology for science and social studies }\end{array}$ & & $\begin{array}{l}0.87 \\
6\end{array}$ & & 4.063 & 0.777 \\
\hline $\begin{array}{l}\text { 13. Identify research methods used in the teaching } \\
\text { methodology for science and social studies }\end{array}$ & & $\begin{array}{l}0.81 \\
6\end{array}$ & & 4.099 & 0.852 \\
\hline $\begin{array}{l}\text { 14. Describe how the idea to introduce the subject } \\
\text { "Science and social studies" in schools was developed }\end{array}$ & & $\begin{array}{l}0.70 \\
7\end{array}$ & & 3.891 & 0.897 \\
\hline $\begin{array}{l}\text { 15. Define learning outcomes of the subject "Science } \\
\text { and social studies" }\end{array}$ & & $\begin{array}{l}0.65 \\
0\end{array}$ & & 4.225 & 0.794 \\
\hline $\begin{array}{l}\text { 16. Identify principles of organization of the "Science } \\
\text { and social studies" subject content }\end{array}$ & & $\begin{array}{l}0.55 \\
3\end{array}$ & & 4.036 & 0.841 \\
\hline $\begin{array}{l}\text { 17. Describe curriculum contents related to the economy } \\
\text { (agriculture, industry, trades and crafts, services) }\end{array}$ & & & $-\overline{0} \cdot 915$ & 3.666 & 1.081 \\
\hline $\begin{array}{l}\text { 18. Define curriculum contents related to history (time } \\
\text { orientation, historical images, history of objects and } \\
\text { phenomena, etc.) }\end{array}$ & & & $\overline{0}-853$ & 3.612 & 1.063 \\
\hline $\begin{array}{l}\text { 19. Identify curriculum contents related to traffic } \\
\text { education }\end{array}$ & & & $\overline{-}-801$ & 3.639 & 1.025 \\
\hline
\end{tabular}


20. Define curriculum contents related to geography (spatial orientation, cartographic literacy, relief, etc.)

21. Identify curriculum contents related to natural sciences (living beings and living communities; inanimate nature: water, air, soil, warmth, light)

22. Define health-related curriculum contents (health and nutrition, childhood diseases, pathogens, etc.)

23. Name different approaches to assessment and methods for evaluation and assessment of students' achievements in the Science and social studies class

Factor 1: Familiarity with didactic and methodological contents of Science Teaching Methodology

Factor 2: Familiarity with the key features of the subject "Science and social studies"

Factor 3: Familiarity with the essential curriculum contents of Science Teaching Methodology

*To facilitate interpretation, factor saturations whose absolute value exceeds 0.3 have been shown.

On the basis of the data obtained (Table 3) for the subscale Familiarity with didactic and methodological contents of Science Teaching Methodology we can see that the respondents have attributed the highest value $(\mathrm{M}=4.25)$ to the item named Describe specific traits of social forms of teaching in the course on Science and social studies. The lowest value $(\mathrm{M}=3.72)$, as well as the highest standard dispersion of results $(\mathrm{SD}=1.03)$, has been obtained for the item named Define personal and professional characteristics and competences of a successful teacher. The lowest dispersion $(\mathrm{SD}=0.79)$ has been obtained for the item Define teaching strategies, methods and procedures. The analysis of results obtained for the subscale Familiarity with the key features of the subject "Science and social studies" shows that the highest mean value $(\mathrm{M}=4.22)$ was obtained for the item Define tasks of the subject "Science and social studies", while the lowest mean value $(\mathrm{M}=3.89)$ was obtained for the item Describe how the idea to introduce the subject "Science and social studies" in schools was developed. A possible explanation for such high mean values related to this scale is the fact that students of the said course are aware of interdisciplinarity and complexity of this school subject, whose purpose is to acquaint pupils with scientific and social aspects of knowledge about the environment in which they live. Items of the subscale Familiarity with the essential curriculum contents of Science Teaching Methodology were attributed generally lover average values and higher dispersions in comparison with the previous two subscales, which is probably the result of difficulties in processing such a complex and comprehensive course which incorporates curriculum contents from both natural and social sciences and humanities that are an integral part of the Science Teaching Methodology. Looking at the overall score (Table 3), we can conclude that the respondents attributed high levels of importance (from $M=3.61$ to $M=4.25$ ) to all three subscales which are related to the construct Acquisition of theoretical knowledge and which deal with the essential curriculum contents and methodological knowledge of science and social studies.

The conducted factor analysis has shown that concrete experience with Science Teaching Methodology is a multi-dimensional construct. Two factors have been singled out whose characteristic root is greater than 1 (characteristic roots of the two selected factors: 6.953 and 3.723 ) and which account for $56.185 \%$ of the scale score variance. With regard to the size of the coefficient in the matrix shown in Table 4, the first factor was named Experience related to didactic and methodical factors of the Science and social studies class delivery (items 1 to 10), while the second factor was named Experience with the delivery of Science and social studies classes (items 11 to 18). On the basis of the aforementioned factor analysis, two eponymous subscales have been constructed.

Propósitos y Representaciones

Aug. 2020, Vol. 8, SPE(2), e685

http://dx.doi.org/10.20511/pyr2020.v8nSPE2.685 
Table 4.

Results of the factor analysis for the scale Concrete experience with the Science Teaching Methodology and descriptive statistics of the items of the scale

\begin{tabular}{|c|c|c|c|c|}
\hline \multirow[t]{2}{*}{ Concrete experience with Science Teaching Methodology } & \multicolumn{2}{|c|}{ Factor* } & \multirow{2}{*}{$\begin{array}{l}\text { Arithmetic } \\
\text { mean }\end{array}$} & \multirow{2}{*}{$\begin{array}{l}\text { Standard } \\
\text { deviation }\end{array}$} \\
\hline & 1 & 2 & & \\
\hline 1. Analysis of manuals for elementary school teachers & 0.875 & & 2.927 & 1.359 \\
\hline $\begin{array}{l}\text { 2. Description of concrete obstacles to learning (insufficient } \\
\text { prior knowledge, lack of effective learning strategies, } \\
\text { misconceptions about the subject's curriculum content, etc.) }\end{array}$ & 0.811 & & 3.090 & 1.276 \\
\hline $\begin{array}{l}\text { 3. Analysis of the student's textbook for Science and social } \\
\text { studies class }\end{array}$ & 0.792 & & 3.288 & 1.330 \\
\hline 4. Writing lesson plans for combined classes & 0.765 & & 2.432 & 1.405 \\
\hline $\begin{array}{l}\text { 5. Explanation of different learning styles and individual } \\
\text { needs of learners in Science and social studies class }\end{array}$ & 0.713 & & 3.135 & 1.179 \\
\hline 6. Drafting the annual curriculum implementation plan & 0.687 & & 3.405 & 1.267 \\
\hline $\begin{array}{l}\text { 7. Designing objective-type assignments from the Science } \\
\text { and social studies curriculum }\end{array}$ & 0.681 & & 3.396 & 1.169 \\
\hline $\begin{array}{l}\text { 8. Assessment of objective-type assignments from Science } \\
\text { and social studies curriculum }\end{array}$ & 0.674 & & 3.261 & 1.141 \\
\hline 9. Drafting the monthly curriculum implementation plan & 0.668 & & 3.378 & 1.293 \\
\hline $\begin{array}{l}\text { 10. Analysis of Science and social studies curriculum for the } \\
\text { first four grades of primary school }\end{array}$ & 0.520 & 0.382 & 4.036 & 1.035 \\
\hline $\begin{array}{l}\text { 11. Consulting with a teacher-methodologist about the } \\
\text { practical implementation of methodology exercises for } \\
\text { Science and social studies class }\end{array}$ & & 0.854 & 4.306 & 0.871 \\
\hline $\begin{array}{l}\text { 12. Consulting with the teacher-mentor about the practical } \\
\text { implementation of methodology exercises for Science and } \\
\text { social studies class }\end{array}$ & & 0.853 & 4.279 & 0.955 \\
\hline $\begin{array}{l}\text { 13. Direct observation of delivery of a Science and social } \\
\text { studies class (other teachers, teacher-mentor, students) }\end{array}$ & & 0.803 & 4.117 & 1.068 \\
\hline $\begin{array}{l}\text { 14. Choice of teaching strategies, methods, techniques and } \\
\text { procedures in accordance with the learning outcomes }\end{array}$ & & 0.802 & 4.117 & 0.839 \\
\hline $\begin{array}{l}\text { 15. Analysis of examples of Science and social studies lessons } \\
\text { (different approaches) }\end{array}$ & & 0.801 & 4.009 & 0.958 \\
\hline 16. Formulating educational learning outcomes & & 0.740 & 4.189 & 0.879 \\
\hline $\begin{array}{l}\text { 17. Personal delivery of a lesson within Science and social } \\
\text { studies teaching methodology exercises }\end{array}$ & & 0.604 & 4.189 & 0.939 \\
\hline 18. Drafting a plan for delivering a specific teaching top & & 0.582 & 4.432 & 0.770 \\
\hline
\end{tabular}

Factor 1: Experience related to didactic and methodical factors of the Science and social studies class delivery

Factor 2: Experience with the delivery of Science and social studies classes

*To facilitate interpretation, factor saturations whose absolute value exceeds 0.3 have been shown.

The analysis of the items within the subscale Experience related to didactic and methodical factors of the Science and social studies class delivery shows that the respondents attributed the highest value $(\mathrm{M}=4.03)$ to the item Analysis of Science and social studies curriculum for the first four grades of primary school, while the lowest value $(M=2.43)$ was attributed to the item Writing lesson plans for combined classes, which was also characterized by the highest dispersion of results $(\mathrm{SD}=1.40)$. Furthermore, the conducted statistical analysis of the items of the subscale Experience with the delivery of Science and social studies classes shows that the highest average mean value $(\mathrm{M}=4.43)$ and the lowest dispersion $(\mathrm{SD}=0.77)$ are associated with the item Writing lesson plans. Also, high average values $(\mathrm{M}=4.30 ; \mathrm{M}=4.27)$ have been observed for the items Consulting with a teacher-methodologist and the teacher-mentor. The lowest average value $(\mathrm{M}=4.01)$ has been observed for the item Analysis of examples of Science 
and social studies lessons, while the highest dispersion of results $(\mathrm{SD}=1.06)$ has been observed for the item Direct observation of delivery of a Science and social studies class by other teachers.

If we compare the results obtained for these two subscales (Table 4), we notice that the most frequently encountered concrete experiences mentioned by respondents are those related to writing lesson plans and delivering Science and social studies classes $(M=4.18)$, while the least frequent experiences mentioned by students are those related to working in combined classes in local schools $(M=2.43)$, analysing supplementary didactic materials for teachers $(M=2.92)$, and identifying concrete obstacles to learning $(M=3.09)$. These results can be explained by the fact that within this course students acquire a certain degree of concrete experience in the course of their lectures and their school practice, although they might lack a broader perspective on practical teaching which would include alternative manners of organizing and delivering classes, as well as a more thorough study of different learning styles and individual learner needs, potential obstacles to learning, and supplementary teaching materials, such as teaching manuals.

\section{Results of factor and descriptive analysis in teacher training}

The conducted factor analysis has shown that reflective observation in the Science Teaching Methodology is a multi-dimensional construct. Two factors with the characteristic root greater than 1 (characteristic roots of the two selected factors: 7.930 and 1.707) have been singled out, accounting for $60.233 \%$ of the scale score variance. With regard to the size of the coefficient, the first factor was named Reflection on the links between theory and practice in Science and social studies classes (items 1 to 12), and the second factor was named Reflection on the delivery of Science and social studies classes (items 13 to 16). On the basis of the said factor analysis, two eponymous subscales have been constructed (Table 5).

Table 5.

Results of the factor analysis of the scale Reflective observation in the Science Teaching Methodology and descriptive statistics of the items of the scale

\begin{tabular}{|c|c|c|c|c|}
\hline \multirow{2}{*}{$\begin{array}{l}\text { Reflective observation in the Science Teaching } \\
\text { Methodology }\end{array}$} & \multicolumn{2}{|c|}{ Factor* } & \multirow{2}{*}{$\begin{array}{l}\text { Arithmetic } \\
\text { mean }\end{array}$} & \multirow{2}{*}{$\begin{array}{l}\text { Standard } \\
\text { deviation }\end{array}$} \\
\hline & 1 & 2 & & \\
\hline $\begin{array}{l}\text { 1. Analysis of the pedagogical and didactic theories } \\
\text { employed during a Science and social studies lesson }\end{array}$ & 0.860 & & 3.481 & 1.106 \\
\hline $\begin{array}{l}\text { 2. Analysis of learning theories on which the Science and } \\
\text { social studies teaching activity was based }\end{array}$ & 0.822 & & 3.445 & 1.054 \\
\hline $\begin{array}{l}\text { 3. Analysis of emotions stirred by living and/or evoking the } \\
\text { experience of delivering a Science and social studies class }\end{array}$ & 0.784 & & 3.363 & 1.114 \\
\hline $\begin{array}{l}\text { 4. Explaining the teaching strategies, methods and } \\
\text { procedures used in Science and social studies classes }\end{array}$ & 0.761 & & 3.854 & 0.975 \\
\hline $\begin{array}{l}\text { 5.Explaining one's own actions, beliefs, values and motives } \\
\text { in a Science and social studies lesson }\end{array}$ & 0.750 & & 3.581 & 1.103 \\
\hline $\begin{array}{l}\text { 6. Linking the achieved educational objectives with tasks } \\
\text { and chosen methodological procedures }\end{array}$ & 0.749 & & 3.863 & 0.933 \\
\hline $\begin{array}{l}\text { 7. Explanation of different classroom management styles } \\
\text { and manners of addressing disciplinary issues }\end{array}$ & 0.745 & & 3.481 & 1.011 \\
\hline $\begin{array}{l}\text { 8. Analysis of the teacher-mentor's personal pedagogical } \\
\text { documentation (lesson plan, planning and programming, } \\
\text { etc.) related to a Science and social studies class }\end{array}$ & 0.721 & & 3.445 & 1.223 \\
\hline 9. Analysis of an educational show or a journal for children & 0.702 & $-\overline{0.427}$ & 2.372 & 1.171 \\
\hline 10. Analysis of personal opi & 0.692 & & 3.627 & 1.073 \\
\hline
\end{tabular}

uncertainties about the delivery of Science and social studies classes 
11. Analysis of objectives and learning outcomes achieved 0.597 during a Science and social studies class

12. Explaining one's own difficulties in delivering Science 0.563 and social studies classes

13. Analysis of one's own class delivered in cooperation with a teacher-methodologist, teacher-mentor and other students

14. Analysis of a directly observed class (social forms of teaching used, teaching methods and procedures used, achieved objectives and lesson articulation)

15. Analysis of feedback from a teacher-methodologist about the delivery of a Science and social studies class 16. Analysis of feedback from the teacher-mentor about the delivery of a Science and social studies class

Factor 1: Reflection on the links between theory and practice in Science and social studies classes Factor 2: Reflection on the delivery of Science and social studies classes

*To facilitate interpretation, factor saturations whose absolute value exceeds 0.3 have been shown.

Results of the subscale Reflection on the links between theory and practice in Science and social studies classes show that the highest mean value $(\mathrm{M}=3.86)$ and the lowest dispersion of results $(\mathrm{SD}=0.93)$ is associated with the item Links between achieved education objectives and tasks and methodological procedures. The lowest average mean value $(M=2.37)$ has been observed for the item Analysis of an educational show or a journal for children, while the highest dispersion of results $(\mathrm{SD}=1.22)$ was observed for the item Analysis of personal pedagogical documentation of the teacher-mentor.

The analysis of results of the subscale Reflection on the delivery of Science and social studies classes has shown that the lowest average mean value $(M=3.64)$ has been observed for the item Explaining one's own difficulties in delivering Science and social studies classes, while the highest dispersion $(\mathrm{SD}=1.12)$ has been observed for the item Analysis of feedback from the teacher-mentor about the delivery of a Science and social studies class. The item with the highest arithmetic mean $(\mathrm{M}=4.13)$ is the Analysis of one's own class delivered in cooperation with other teachers, while the lowest standard deviation $(\mathrm{SD}=0.92)$ has been observed for the item Analysis of a directly observed class. The results obtained by means of the descriptive and factor analysis of both subscales (Table 5) show a higher degree of reflection about the structure and delivery of the lesson in comparison to the reflection about the use of pedagogical and didactic theories and personal impressions (e.g. emotions and difficulties) of students during a lesson. The presented results seem to suggest that the majority of respondents practice reflection without a deeper analysis of theoretical foundations on which teaching and learning are based, failing to draw links between methodological theory and practice.

This conclusion is supported by theoretical contemplations by several authors (Striano, 2001; Valenčić-Zuljan \& Vogrinc, 2012; Korthagen et al., 2001; Altet et al., 2006) who argue that technical and rational models which do not include a deeper reflection on one's own teaching practice are still being used in methodology exercises and pedagogical practice. Students are doing their best to harmonize their class delivery with the prescribed models or guidelines for educational work, while assessment consists of checking whether the delivery is in line with the expectations of mentors and teachers-methodologists and of pointing out mistakes of technical and procedural character. Furthermore, in her research, M. Striano (2001) encountered logistic and organizational difficulties which impair a conscious and systematic articulation and awareness of reflective processes which occur during educational work. This comment by $\mathrm{M}$. Striano can be linked with a commonly encountered lack of an appropriate space and time for the analysis of a lesson in training schools. Teachers-mentors need to continue working with pupils, while students are required to continue fulfilling other course obligations at the faculty/department. 
Another opinion we find interesting is that presented by M. Fullan and A. Hargreaves (Fullan \& Hargreaves, 2005), who argue that teachers' reflection-in-action and reflection-onaction (Schön, 1987), i.e. reflection during and after delivering a class, is mostly based on impressions gained during dynamic, tumultuous and hectic events which are typical for classroom life and that such evaluations, although useful, are not sufficient for a deeper analysis of the teaching practice. Namely, individual experience and reflection comprise only a small part of the teaching practice, which needs to be linked with other experiences and theoretical assumptions. For reflection to be truly thorough, it requires "a different pair of eyes", i.e. it needs to be observed from another perspective apart from the one based on the general impression of effectiveness of a specific education situation. Additionally, these forms of reflection usually lack a critical consideration of objectives and principles on which the teaching activity is based, of the level of cognitive activity of pupils, of an equal participation of all pupils in the activity, and of the influence of the context on the effectiveness of the teaching process (Fullan \& Hargreaves, 2005). However, it is important to emphasize that critical thinking skills do not develop spontaneously, but need to be systematically developed in the course of teachers' initial training and later professional development, which is also confirmed by research by B. Bognar (2009) and L. Mortari (2011).

The conducted factor analysis has shown that abstract conceptualization in Science Teaching Methodology is a one-dimensional construct. One factor with characteristic root greater than 1 (characteristic root: 5.614) has been singled out, accounting for $70.180 \%$ of the scale score variance. This factor was named Links between theoretical insights and methodological delivery of Science and social studies classes (items 1 to 8) (Table 6). On the basis of the said factor analysis, a single eponymous scale has been constructed.

Table 6.

Results of the factor analysis of the scale abstract conceptualization in the Science Teaching Methodology and the descriptive statistics of the items of the scale

\begin{tabular}{|c|c|c|c|}
\hline $\begin{array}{l}\text { Abstract conceptualization in the Science Teaching } \\
\text { Methodology }\end{array}$ & $\begin{array}{l}\text { Factor* } \\
1\end{array}$ & $\begin{array}{l}\text { Arithmetic } \\
\text { mean }\end{array}$ & $\begin{array}{l}\text { Standard } \\
\text { deviation }\end{array}$ \\
\hline $\begin{array}{l}\text { 1. Linking acquired experiential knowledge with theoretical } \\
\text { insights into the methodological issues of teaching Science and } \\
\text { social studies classes }\end{array}$ & 0.890 & 3.270 & 1.086 \\
\hline $\begin{array}{l}\text { 2. Proposing solutions for concrete difficulties, problems and } \\
\text { obstacles in a teaching situation }\end{array}$ & 0.855 & 3.072 & 1.173 \\
\hline 3. Devising and proposing changes for schools for the future & 0.852 & 3.036 & 1.190 \\
\hline $\begin{array}{l}\text { 4. Finding connections between specific factors in Science and } \\
\text { social studies classes }\end{array}$ & 0.842 & 3.189 & 1.124 \\
\hline $\begin{array}{l}\text { 5. Linking theoretical postulates from psychology and pedagogy } \\
\text { with personal findings about the delivery of Science and social } \\
\text { studies classes }\end{array}$ & 0.831 & 3.099 & 1.111 \\
\hline $\begin{array}{l}\text { 6. Presenting personal findings about teaching Science and } \\
\text { social studies in papers written for professional/scientific } \\
\text { conferences or pedagogical journals }\end{array}$ & 0.818 & 2.747 & 1.209 \\
\hline $\begin{array}{l}\text { 7. Linking personal findings about teaching science and social } \\
\text { studies concepts with learning and teaching theories }\end{array}$ & 0.817 & 3.144 & 1.142 \\
\hline $\begin{array}{l}\text { 8. Creating proposals for new approaches to methodological } \\
\text { issues of teaching science and social studies }\end{array}$ & 0.794 & 2.955 & 1.155 \\
\hline $\begin{array}{l}\text { Factor 1: Links between theoretical insights and methodological } \\
\text { classes }\end{array}$ & & & \\
\hline
\end{tabular}

Analysis (Table 6) of the items of the scale named Links between theoretical insights and methodological delivery of Science and social studies classes shows that the item Linking 
acquired experiential knowledge with theoretical insights into the methodological issues of teaching Science and social studies classes has the highest mean value $(M=3.27)$, while the lowest mean value $(\mathrm{M}=2.74)$, as well as the highest dispersion ( $\mathrm{SD}=1.21)$, has been observed for the item Presenting personal findings about teaching Science and social studies in papers written for professional/scientific conferences or pedagogical journals.

The obtained results of factor and descriptive analysis of the previous scale could partially be explained by a lack of review of the teaching practice and a lack of critical thinking about the lived experience among students. Another possible reason for the low average values obtained for abstract conceptualization in Science Teaching Methodology might be the insufficient motivation of university teachers to conduct joint research and publish papers together with students, in journals or in conference proceedings. Apart from that, it is our belief that future teachers, i.e. students of teacher education studies, lack support in the organization of forums and learning communities by means of which they might discuss with other students, school teachers, teachersmentors and pedagogues about their practical experiences in light of the most important theories of learning and teaching. Such discussions might provide a clearer interpretation of the results achieved in practice.

Indispensability of reflection about the delivered classes, which is essential for any deeper analysis of the professional activity, is confirmed by research by B. Bognar (2009) about the introduction of substantial changes in teaching. Teachers involved in Bognar's action research have repeatedly emphasized the importance of a critical evaluation of one's own teaching practice, as the awareness of a lack of teaching experience fosters the introduction of changes, especially if they are discussed with critical friends, in learning communities or forums, which allows one to gain a broader perspective of the issue. However, in the course of his research, Bognar has noticed that the willingness to discuss and exchange experiences is not always readily accepted; rather, it is frequently met with a certain degree of resistance and refraining from sincere comments. Therefore it is advisable to encourage this form of work already during teachers' initial training.

The conducted factor analysis has shown that active experimentation in Science Teaching Methodology is a one-dimensional construct. One factor whose characteristic root is greater than 1 (characteristic root of the factor: 5.469) has been singled out, accounting for $60.764 \%$ of the scale score variance. That factor was named the Use of acquired knowledge and innovations in Science and social studies classes (items 1 to 9) (Table 7). On the basis of the aforementioned factor analysis, one eponymous scale has been constructed. If we examine the scale (Table 7) Use of acquired knowledge and innovations in science and social studies classes, we can observe that the respondents attributed the highest average $(M=3.12)$, although rather inhomogeneous values $(\mathrm{SD}=1.13)$ to the item Creating didactic games. Although highest in comparison with other scale scores, the obtained average value is relatively low and non-homogeneous. The lowest average values have been obtained for the items Microteaching $(\mathrm{M}=2.09)$ and Carrying out smaller research assignments $(\mathrm{M}=2.25)$. The obtained results of the factor analysis and descriptive analysis show that the majority of students rarely introduce new procedures during their demonstration lessons of Science and social studies, and that the new elements are usually limited by the available choice of teaching technology. Furthermore, the obtained results indicate that research assignments are not frequently implemented in the Science Teaching Methodology. 
Table 7.

Results of the factor analysis of the scale active experimentation in Science Teaching Methodology and the descriptive statistics of the items of the scale

\begin{tabular}{|c|c|c|c|}
\hline Active experimentation in Science Teaching Methodology & $\begin{array}{l}\text { Factor* } \\
1\end{array}$ & $\begin{array}{l}\text { Arithmetic } \\
\text { mean }\end{array}$ & $\begin{array}{l}\text { Standard } \\
\text { deviation }\end{array}$ \\
\hline $\begin{array}{l}\text { 1. Development of a supplementary instrument for monitoring } \\
\text { students' progress }\end{array}$ & 0.840 & 2.718 & 1.204 \\
\hline $\begin{array}{l}\text { 2. Carrying out smaller research assignments (e.g. the extent to } \\
\text { which ICT is used in the training centre for teaching science and } \\
\text { social studies concepts) }\end{array}$ & 0.836 & 2.254 & 1.207 \\
\hline $\begin{array}{l}\text { 3. Description of the innovations introduced in school practice, } \\
\text { based on reflective practice and action research on science and social } \\
\text { studies classes }\end{array}$ & 0.835 & 2.609 & 1.142 \\
\hline $\begin{array}{l}\text { 4. Re-delivering the same teaching unit from the Science and social } \\
\text { studies curriculum with the introduction of new elements }\end{array}$ & 0.834 & 2.336 & 1.213 \\
\hline $\begin{array}{l}\text { 5. Description of the conducted action research about concrete } \\
\text { methodological issues in science and social studies classes }\end{array}$ & 0.815 & 2.572 & 1.266 \\
\hline $\begin{array}{l}\text { 6. Developing precise criteria for assessment of pupils' knowledge } \\
\text { at different levels according to the selected taxonomy }\end{array}$ & 0.792 & 2.636 & 1.147 \\
\hline $\begin{array}{l}\text { 7. Microteaching - a short simulation of teaching situations from the } \\
\text { science and social studies curriculum, recorded by means of a video } \\
\text { camera and then analysed }\end{array}$ & 0.790 & 2.090 & 1.161 \\
\hline $\begin{array}{l}\text { 8. Creating didactic games (for environmental education, traffic } \\
\text { education etc.) }\end{array}$ & 0.675 & 3.127 & 1.134 \\
\hline $\begin{array}{l}\text { 9. Participation in practice communities for the purpose of } \\
\text { comparing experiences }\end{array}$ & 0.550 & 3.072 & 1.155 \\
\hline
\end{tabular}

On the one hand, the lack of active experimentation at Faculties of Teacher Education is understandable due to a lack of adequate facilities and working conditions in which such forms of teaching can be implemented, but also due to students' insufficient experience, which prevents them from influencing more significant changes in the education process, especially if they lack support from their teachers-methodologists and teachers-mentors. This is further supported by B. Bognar's (2009) view according to which significant innovations include changes in both the values and the theoretical understanding of the education process, as well as adoption and development of a new educational philosophy, which students cannot be expected to do. On the other hand, the development of the teacher-researcher, who will analyse and evaluate his or her own class delivery and students' learning process in order to improve his or her own teaching practice, is being neglected, although willingness and openness to change is considered a desirable characteristic of teachers for the future (Razdevšek Pučko, 2005; Polić, 2006).

Seen that the questionnaire was constructed specifically for the purpose of this research and that the items in the scales have never been used before, it was necessary to establish the internal reliability coefficient for some of the scales and subscales, which was done by means of the Cronbach's alpha coefficient. Analysis has shown that all scales have satisfactory reliability coefficients of the internal consistency type, ranging between $0.80(\alpha=0.863)$ and $0.93(\alpha=$ 0.932).

In order to get a clearer image of the average results of individual subscales and scales, factor reduction was conducted and descriptive statistics, symmetry and kurtosis were calculated (Table 8). The highest average and relatively homogeneous results $(\mathrm{M}=4.17 ; \mathrm{SD}=0.67)$ were obtained for the subscale Experience with the implementation and delivery of Science and social studies classes. In the same subscale, a strong negative asymmetry has been observed ( $\mathrm{S}=-1.07)$, 
which means that the results are grouped around high values. On the basis of the obtained results it can be concluded that the lesson preparation and delivery under the guidance of the teachermentor and a teacher-methodologist is one of the predominant professional experiences within this methodology. However, we wonder how sufficient is the professional training of future teachers which is based only on the acquisition of practical experiences related to the delivery of new teaching contents and use of classroom management techniques?

Table 8.

Descriptive statistics, symmetry, kurtosis and reliability of scales and subscales (Science Teaching Methodology)

\begin{tabular}{|c|c|c|c|c|c|c|c|}
\hline \multicolumn{2}{|c|}{ Name of scale or subscale } & \multirow{2}{*}{$\begin{array}{l}\mathrm{N} \\
110\end{array}$} & \multirow{2}{*}{$\begin{array}{l}\mathrm{M} \\
3.971\end{array}$} & \multirow{2}{*}{$\frac{\text { SD }}{0.630}$} & \multirow{2}{*}{$\begin{array}{l}S \\
-0.862\end{array}$} & \multirow{2}{*}{$\begin{array}{l}\mathrm{K} \\
1.469\end{array}$} & \multirow{2}{*}{$\begin{array}{l}\text { alpha } \\
0.893\end{array}$} \\
\hline $\begin{array}{l}\text { Knowledge } \\
\text { acquisition }\end{array}$ & $\begin{array}{l}\text { 1.a Familiarity with didactic / methodology-related } \\
\text { curriculum contents of the Science Teaching } \\
\text { Methodology }\end{array}$ & & & & & & \\
\hline & $\begin{array}{l}\text { 1.b Familiarity with the key features of the subject } \\
\text { "Science and social studies" }\end{array}$ & 111 & 4.063 & 0.670 & -0.488 & -0.266 & 0.863 \\
\hline & $\begin{array}{l}\text { 1.c Familiarity with the essential curriculum contents } \\
\text { of the Science Teaching Methodology }\end{array}$ & 111 & 3.736 & 0.872 & -0.842 & 0.559 & 0.932 \\
\hline \multirow[t]{2}{*}{$\begin{array}{l}\text { Concrete } \\
\text { experience }\end{array}$} & $\begin{array}{l}\text { 2.a Experience with didactic and methodical factors } \\
\text { of the Science Teaching Methodology }\end{array}$ & 111 & 3.235 & 0.914 & -0.330 & -0.455 & 0.903 \\
\hline & $\begin{array}{l}\text { 2.b Experience with the implementation and delivery } \\
\text { of Science and social studies classes }\end{array}$ & 111 & 4.172 & 0.676 & -1.072 & 0.991 & 0.894 \\
\hline \multirow[t]{2}{*}{$\begin{array}{l}\text { Reflective } \\
\text { observation }\end{array}$} & $\begin{array}{l}\text { 3.a Reflection on links between theory and practice in } \\
\text { Science Teaching Methodology }\end{array}$ & 110 & 3.498 & 0.802 & -0.692 & 0.322 & 0.927 \\
\hline & $\begin{array}{l}\text { 3.b Reflection on the delivery of Science and social } \\
\text { studies classes }\end{array}$ & 110 & 3.984 & 0.862 & -0.981 & 0.901 & 0.804 \\
\hline $\begin{array}{l}\text { Abstract } \\
\text { conceptualization }\end{array}$ & $\begin{array}{l}\text { 4. Links between theoretical insights and } \\
\text { methodological delivery of Science and social studies }\end{array}$ & 111 & 3.064 & 0.916 & -0.180 & -0.929 & 0.934 \\
\hline $\begin{array}{l}\text { Active } \\
\text { experimentation }\end{array}$ & $\begin{array}{l}\text { 5. Use of acquired knowledge and innovations in } \\
\text { Science and social studies classes }\end{array}$ & 110 & 2.602 & 0.961 & -0.030 & -0.490 & 0.917 \\
\hline
\end{tabular}

Unfortunately, exemplary activities such as accompanying pupils on school trips and excursions, organization of integrated and extra-classroom teaching, outdoor education and similar is still only rarely encountered, which is understandable to a certain extent, as it is technically difficult to implement such forms of teaching in the current conditions of cooperation between teacher education faculties and training schools, especially when it comes to the implementation of methodology exercises. Extra-classroom teaching and outdoor education are costly and no financial resources have been allocated for these activities, neither in training schools nor in higher education institutions. Furthermore, in order to enable participation of students in extra-classroom teaching, outdoor education, and winter or summer holidays, it is necessary to provide longer periods of student practice in the curricula of teacher education studies, with a higher level of responsibility as well as practical experience with organizing and implementing such forms of teaching.

The lowest average value $(\mathrm{M}=2.60)$ has been obtained for the scale Using the acquired knowledge and innovations in Science and social studies classes, which is also characterized by the highest standard dispersion ( $\mathrm{SD}=0.96$ ), indicating that students' answers in this scale were relatively heterogeneous and that their experiences with introducing innovations in methodology exercises for Science and social studies classes differ significantly. As mentioned before, students cannot be expected to introduce substantial changes in conceptions of teaching and in study programs or to solve problems of the school system, but they can be encouraged to make changes related to their personal and professional development, learning process, teaching strategies, teacher-student relationship, creative learning and similar. How successful their efforts will be depends on numerous factors, among which the most crucial ones are school atmosphere, support of teachers-methodologists, friendly and cooperative relationship with teachers-mentors, and students' willingness to introduce innovations, i.e. their resistance to or fear of change. 
The obtained correlations among scales and subscales (Table 9) are mostly positive and statistically significant, whereas the highest degree of positive correlation $(r=0.811 ; p<0.01)$ has been observed between the scales Links between theoretical insights and methodological delivery of Science and social studies classes and Use of the acquired knowledge and innovations in Science and social studies classes. In this case, the correlation between the two aforementioned scales was expected, because students need to be able to implement the acquired theoretical knowledge in practice during their lectures on methodological issues of Science and social studies classes. A high degree of correlation $(r=0.739 ; \mathrm{p}<0.01)$ between subscales Familiarity with the essential curriculum contents and Familiarity with didactic/methodology-related curriculum contents of the Science Teaching Methodology indicates an interdependence of pedagogical and psychological sciences and substrate sciences in the Science Teaching Methodology.

Table 9.

Correlations among scales and subscales of the Science Teaching methodology questionnaire

\begin{tabular}{|c|c|c|c|c|c|c|c|c|c|}
\hline \multirow{2}{*}{$\begin{array}{l}\text { Name of scale and } \\
\text { subscale }\end{array}$} & \multicolumn{9}{|c|}{ Pearson's correlation among scales and subscales } \\
\hline & $1 . \mathrm{a}$ & $1 . \mathrm{b}$ & $1 . \mathrm{c}$ & $2 . \mathrm{a}$ & $2 . \mathrm{b}$ & $3 . \mathrm{a}$ & 3.b & 4. & 5 . \\
\hline $\begin{array}{l}\text { 1.a Familiarity with } \\
\text { didactic/methodology- } \\
\text { related curriculum } \\
\text { contents of Science } \\
\text { Teaching }\end{array}$ & 1 & & & & & & & & \\
\hline $\begin{array}{l}\text { Methodology } \\
\text { 1.b Familiarity with } \\
\text { key features of the } \\
\text { subject "Science and } \\
\text { social studies" }\end{array}$ & $0.612 * *$ & 1 & & & & & & & \\
\hline $\begin{array}{l}\text { 1.c Familiarity with } \\
\text { the essential } \\
\text { curriculum contents of } \\
\text { the Science teaching } \\
\text { methodology }\end{array}$ & $0.739^{* *}$ & $0.607 * *$ & 1 & & & & & & \\
\hline $\begin{array}{l}\text { 2.a Experience with } \\
\text { didactic/methodology- } \\
\text { related factors of } \\
\text { Science and social } \\
\text { studies classes }\end{array}$ & $0.443 * *$ & $0.266^{* *}$ & $0.557^{* *}$ & 1 & & & & & \\
\hline $\begin{array}{l}\text { 2.b Experience with } \\
\text { the delivery of Science } \\
\text { and social studies } \\
\text { classes }\end{array}$ & $0.509^{* *}$ & $0.513^{* *}$ & $0.398 * *$ & $0.322 * *$ & 1 & & & & \\
\hline $\begin{array}{l}\text { 3.a Reflection on the } \\
\text { links between theory } \\
\text { and practice in } \\
\text { Science and social } \\
\text { studies classes }\end{array}$ & $0.417^{* *}$ & $0.291^{* *}$ & $0.390 * *$ & $0.620 * *$ & $0.467 * *$ & 1 & & & \\
\hline $\begin{array}{l}\text { 3.b Reflection on the } \\
\text { delivery of Science } \\
\text { and social studies } \\
\text { classes }\end{array}$ & $0.290^{* *}$ & $0.400^{* *}$ & $0.255^{* *}$ & $0.246^{* *}$ & $0.676^{* *}$ & $0.582^{* *}$ & 1 & & \\
\hline $\begin{array}{l}\text { 4. Links between } \\
\text { theoretical insights } \\
\text { and methodological } \\
\text { delivery of Science } \\
\text { and social studies } \\
\text { classes }\end{array}$ & $0.318^{* *}$ & 0.080 & $0.325^{* *}$ & $0.584 * *$ & 0.129 & $0.574 * *$ & $0.313^{* *}$ & 1 & \\
\hline $\begin{array}{l}\text { 5. Use of the acquired } \\
\text { knowledge and } \\
\text { innovations in Science }\end{array}$ & $0.255^{* *}$ & 0.062 & $0.359 * *$ & $0.591 * *$ & 0.027 & $0.538^{* *}$ & $0.203^{* *}$ & $0.811^{\text {*** }}$ & 1 \\
\hline
\end{tabular}


and social studies

classes

$* * \mathrm{p}<0.01 ; * \mathrm{p}<0.05$

There is no correlation between the subscale Familiarity with key features of the subject "Science and social studies" and subscales Links between theoretical insights and methodological delivery of Science and social studies classes $(\mathrm{r}=0.080)$ and Use of the acquired knowledge and innovations in Science and social studies classes $(\mathrm{r}=0.062)$. Furthermore, there is no correlation between the subscale Experience with the delivery of Science and social studies classes and the scales Links between theoretical insights and methodological delivery of Science and social studies classes ( $\mathrm{r}=0.129)$ and Use of the acquired knowledge and innovations in Science and social studies classes $(\mathrm{r}=0.027)$.

The lack of correlation between familiarity with key features of the subject "Science and social studies" and the delivery of classes from that subject was expected, as the organizational structure of the subject Science and social studies is of formal character, which means that the subject is artificially created and named differently in different countries, encompassing various topics from several substrate sciences and organized in accordance with pupils' psycho-physical characteristics rather than with the system of particular scientific areas (De Zan, 1999). The aforementioned characteristics are accepted as such and are not linked with methodological delivery of the subject or with innovations in teaching.

A rather high level of correlation between the constructs related to the links and the use of knowledge from Science Teaching Methodology seems to suggest that the respondents do not perceive the difference between the two constructs. The lack of correlation between the experience with the delivery of Science and social studies classes, abstract conceptualization and use of the acquired knowledge does not necessarily mean that students do not recognize the cyclical process of experiential learning as presented by Kolb (Kolb, 1984, Kolb, 2015) in cognitive processes related to this methodology; rather, they might simply be at one of the stages of experiential learning which does not coincide with the constant change of stages in Kolb's spiral cycle.

Numerous authors have researched the application of the Kolb's experiential learning model in designing and realising study programs (Svinicki \& Dixon, 1987; Sharlanova, 2004; Kolb and Kolb, 2005; Reggio, 2010; Roark \& Norling, 2010), rising the scientific level of research on teaching practices (Sanders \& MacCutcheon, 1986, Mortari, 2011), teaching geography at universities (Healey \& Jenkins, 2000), e-learning (Correia, 2008) and other fields of education. Most research on the application of experiential learning in education have been conducted in higher education. There has been a relatively small number of published research studies on both $\mathrm{K}-12$ education and the education of adults which is most commonly integrated in higher education.

In Croatia the possible application of Kolb's model in education was studied by the author V. Vizek Vidović (Vizek Vidović, 2005; Vizek Vidović, 2011), but not in the field of Science Teaching Methodology and teachers' initial education. Therefore, this research is relevant; it shows that the whole course of a subject can be organised so as to enable students' more successful learning. Namely, for the subject Science Teaching Methodology to be effective and help students become teachers and reflective practitioners, all the steps of the spiral cycle should be included in university teaching, and it includes four phases: experience, reflection, generalisation and application, repeating interchangeably. 


\section{Conclusions}

In selecting the relevant theoretical framework, Kolb's experiential learning model was chosen, which is not easily applicable to our educational conditions and traditions. Furthermore, availability of publications from the studied area of interest in Croatia was rather limited. According to the results obtained by means of a student questionnaire and on the basis of the conducted descriptive and factor analysis, it can be concluded that the aforementioned methodology is dominated by the acquisition of academic and methodological knowledge, whereas the activities of concrete teaching experience are occasionally encountered, the reflection on the lived experience is rarely encountered, and experimentation and introduction of innovations in teaching is very rarely encountered. It can also be concluded that there is a lack of balance between theoretical and practical knowledge, while their mutual integration is insufficient. This confirms both initial hypotheses.

With regard to the obtained results, we can conclude that it is necessary to introduce a greater degree of concrete experience in the initial teacher training curriculum and to integrate it with theoretical knowledge. With regard to the obtained results it is necessary to introduce a greater degree of concrete experience in the initial teacher training curriculum and to integrate it with theoretical knowledge.

\section{References}

Altet, M., Charlier, E., Paquay, L., Perrenoud, Ph. (2006). Formare gli insegnanti professionisti. Quali strategie? Quali competenze? Roma: Armando editore.

Anđić, D. (2007). Learning and teaching nature and society in open spaces. Methodical Horizons, 2(1), 7-23.

Bognar, B. (2009). Making essential changes in educational practice through action research. Educational Sciences, 11(2), 147-162.

Borić, E. (2009). Research teaching nature and society. Osijek: Učiteljski fakultet.

Borić, E., Škugor, A., Perković, I. (2010). Teachers' self-assessment of extracurricular research teaching of nature and society. Educational Sciences, 12(2), 361-373.

Correia, A.P. (2008). A shift from theory to real-world experiences in the e-learning community. Edupoint Magazine, 8(65).

De Zan, I. (1999). Methods of teaching nature and society. Zagreb: Školska knjiga.

De Zan, I. (2005). Methods of teaching nature and society. Zagreb: Školska knjiga.

Fullan, M., Hargreaves, A. (2005). Cosa vale la pena cambiare nella nostra scuola? Trento: Erickson.

Healey, M., Jenkins, A. (2000). Kolb's experiential learning theory and its application in geography in higher education. Journal of Geography, 99, 185-195.

Kolb, A.Y., Kolb, D.A. (2005). Learning styles and learning spaces: Enhancing experiential learning in higher education. Academy of Management Learning \& Education, 4(2), 193212.

Kolb, D.A. (1984). Experiential learning. Experience as the source of learning and development. New Jersey: Prentice Hall.

Kolb, D.A. (2015). Experiential learning: experience as the source of learning and development. New Jersey: Pearson Education.

Kolb, D.A., Fry, R. (1975). Towards an applied theory of experiential learning. New York: Wiley.

Korthagen, F.A.J., Kessels, J., Koster, B., Lagerwerf, B., Wubbels, T. (2001). Linking practice and theory. The pedagogy of realistic teacher education. New York, London: Routledge.

Letina, A. (2016). The effectiveness of research-oriented teaching of nature and society in the development of students' natural science competencies. Croatian Journal of Education, 18(3), 665-696. 
Mortari, L. (2011). Ricercare e riflettere. La formazione del docente professionista. Roma: Carocci editore.

MoSES. (2016). National curriculum for the school subject, „Science and social studies” Retrieved from: http://mzos.hr/datoteke/7-Predmetni_kurikulum-Priroda_i_drustvo.pdf

Passarelli, A.M., Kolb, D.A. (2011). The Learning Way - Learning from Experience as the Path to Lifelong Learning and Development. In book: M. London (Ed.), Handbook of Lifelong Learning. Retrieved from: https://weatherhead.case.edu/departments/organizationalbehavior/workingPapers/WP-09-03.pdf

Polić, M. (2006). Facts and values. Zagreb: Hrvatsko filozofsko društvo.

Razdevšek Pučko, C. (2005). What kind of teacher / teacher does the school need (expected) today (and tomorrow)? Progress, 146(1), 75-90.

Reggio, P. (2010). Guida all'apprendimento esperienziale. Roma: Carocci editore.

Roark, M.F., Norling, J.C. (2010). Anapplication of a modified experiential learning model for a higher education course. Evidence of increased outcomes. Journal of Outdoor Recreation, Education and Leadership, 2(1), 59-73.

Sanders, D., MacChutcheon, G. (1986). The development of practical theories of teaching. Journal of Curriculum and Supervision, 2(1), 50-67.

Schön, D.A. (1987). Toward a new design for teaching and learning in the professions. San Francisco: Jossey Bass.

Sharlanova, V. (2004). Experiential learning. Trakia Journal of Sciences, 2(4), 36-39.

Striano, M. (2001). La "razionalità riflessiva" nell'agire educativo. Napoli: Liguori Editore.

Svinicki, M.D., Dixon, N.M. (1987). The Kolb model modified for classroom activities. College Teaching, 35(4), 141-146.

Szczepanski, A. (2001). What is Outdoor Education? In Other Ways of Learning. In book: 4th Euro Congress of the European Institute of Outdoor Adventure Education and Experiential Learning, pp. 17-24.

Valenčić-Zuljan, M., Vogrinc, J. (2012). Pedagogical Practice and the Process of Developing the Competences of Students of Future Classroom Teachers of the Faculty of Education, University of Ljubljana. In book: M. Valenčić-Zuljan, G. Gojkov, A. Rončević, J. Vogrinc (Eds.). Pedagogical Practice and Process of Developing Competences of Students of Future Teachers in Croatia, Serbia and Slovenia, pp.109-137.

Vizek Vidović, V. (Ed.) (2005). Lifelong teacher education: Multiple perspectives. Zagreb: Institut za društvena istraživanja.

Vizek Vidović, V. (Ed.) (2011). Teachers and their mentors. The role of mentors in the professional development of teachers. Zagreb: Institut za društvena istraživanja.

Vizek Vidović, V., Vlahović-Štetić, V. (2007). Adult learning models and professional development. Chronicle of Social Work, 14 (2), 283-310. 